\title{
Utilization of medicinal plants used in the management of HIVIAIDS opportunistic infections in njeru sub-county, buikwe district, Uganda
}

\begin{abstract}
HIV/AIDS pandemic is currently the largest socio-economic challenge that faces Eastern Africa including Uganda as it affects mostly the young and the most economically productive population. The majority of the people living with HIV/ AIDS are susceptible to bacterial and fungal opportunistic infections that result from immune suppression. However, the increasing acceptance of medicinal plants as an additional and alternative therapeutic strategy to fight against HIV/AIDS opportunistic infections is not adequately documented. The study aimed at assessing the utilization of selected plants used in the management of HIV/AIDS opportunistic infections. Data was collected by ethno-botanical survey. Fifty two (52) medicinal plant species belonging to forty nine (49) genera and thirty one (31) families were identified to be used by the traditional medicinal practitioners (TMPs) in the management of HIV/ AIDS opportunistic infections. Most of these plants were found to belong to families; Lamiaceae, Moraceae, Leguminosae and Verbenaceae. Leaves were the plant part that was predominantly used while drinking of the decoction was the predominant mode of application. Many infections such as skin infections, chronic cough, stomach infection, tuberculosis, diarrhoea, warts, herpes zoster and others were claimed to be treated using medicinal plants.
\end{abstract}

Keywords: HIV/AIDS, herbs, traditional medicine, complementary medicine, environmental, conservation
Volume 5 Issue I - 2018

\author{
Mustapha W Shehu,' Idris Bello, ${ }^{2}$ Nafi'u \\ Abdulkadir, ${ }^{3}$ Abdulazeez Shehu,' Ssenku \\ Ediris Jamil,' Sadiya A Waziri ${ }^{4}$ \\ 'Department of Environmental Science, Islamic University in \\ Uganda, Uganda \\ ${ }^{2}$ Department of Pharmacology, School of Pharmaceutical \\ Sciences, Universiti Sains Malaysia (USM), Malaysia \\ ${ }^{3}$ Department of Microbiology, Sokoto State University, Nigeria \\ ${ }^{4}$ Department of Chemistry, Usmanu Danfodiyo University, \\ Nigeria
}

\begin{abstract}
Correspondence: Mustapha W Shehu, Department of Environmental Science, Faculty of Science, Islamic University in Uganda, Uganda, Tel +23470359l9333,

Email shehumustapha3@gmail.com,
Co-correspondence: Nafi'u Abdulkadir, Department of Microbiology, Faculty of Science, Sokoto State University, Sokoto, Nigeria, Tel +60165466963, Email nafiuabdulkadir523@ gmail.com

Abbreviations: TMPs, traditional medicinal preactitioners; HIV, human immunodeficiency virus; AIDS, acquired immune deficiency syndrome; SPSS, statistical package for social sciences

\section{Introduction}

Human Immunodeficiency Virus (HIV)/Acquired Immune Deficiency Syndrome (AIDS) is a major cause of premature death and imposes a large disease burden around the world (David 2006, 4-5). It reduces progressively the effectiveness of the immune system and leaves the patient susceptible to opportunistic infections. ${ }^{1,2}$ The number people living with HIV/AIDS are steadily increasing. Many of these cases are in the developing countries. HIV/AIDS pandemic is currently the largest socio-economic challenge that faces Eastern Africa including Uganda as it affects mostly the young and most economically productive population. ${ }^{3,4}$ This translates into loss of skills, talents, and expertise. The majority of the people living with HIV/AIDS are susceptible to bacterial and fungal opportunistic infections that result from immune suppression. ${ }^{5,6}$ In Sub-Saharan Africa, traditional healers treat and manage a large number of people with HIV/AIDS. Health facilities are overburdened by the increasing demand for care of HIV/AIDS patients, ${ }^{7,8}$ medicinal plants play a crucial role of providing remedy and also provides health care by taking care of people living with HIV/ AIDS..$^{9,10}$ In Uganda, people use plants as medicines and nutritional supplements in the management of various infections associated with HIV/AIDS which are not documented.
The Global Fund Guidelines (2005) for HIV/AIDS indicate that 135,000 people get infected with the virus every year and most of them are found in Sub-Saharan Africa including Uganda. ${ }^{11-13} \mathrm{HIV} /$ AIDS and other opportunistic infections exert the greatest limitations for health care in the world by causing serious debility, morbidity and mortality in the affected population..$^{14,15}$ It is also regarded as the major factor behind population decrease in the last 10 years in the overall life expectancy in Sub-Saharan Africa. ${ }^{16,17}$ This implies that the majority of 3 the people suffering from HIV/AIDS cannot afford modern health care because of the high cost associated with HIV/AIDS drugs. ${ }^{12,13}$ However, the use of medicinal plant species in Uganda especially in Njeru sub-county persist, and is likely to increase substantially because of the increase in human population, ever increasing cases infections with HIV and other diseases. The high demand for medicinal plants fuels the non-sustainable harvesting of medicinal plant species..$^{18,19}$

This will consequently lead to loss and depletion of wild-harvested medicinal plant species, which in turn will threaten the health care not only in Njeru- Uganda but also worldwide. ${ }^{20,21}$ This is due to lack of a proper strategy of conservation and organizing the commercial trade of the plants and integrating the development from production to consumption. This results to every stakeholder in the medicinal plant sector to have their own interests and thus causing them to ignore the overall development of the sector. ${ }^{22,23}$ Due to degradation of natural vegetation for economic development, genetic erosion and extinction of medicinal plant used in management of HIV opportunistic diseases is rife in Buikwe District (Assistant Environmental ofiicer, personel comm.). 
This is going on at the time when new infections and dependency on herbs is on the rise. The information on plants used in the management of HIV/AIDS opportunistic infections in Uganda is to some extent still scattered and under the custodianship of few individuals who have the knowledge on medicinal plants and are of advanced aged. Further still the effectiveness of these plants in the management of the opportunistic diseases has not been tested. Thus the study focused on documentation of the plants used in the management of HIV/AIDS opportunistic infections before they are lost through degradation of their habitat and death of the elderly people who have the knowledge about them. Also their effectiveness in the management of the opportunistic diseases was assessed.

\section{Materials and methods}

\section{Study area}

Njeru sub-county is located within Buikwe District and it covers an area of $144 \mathrm{sq} . \mathrm{km}$. It is 45 miles East of Kampla, the capital city of Uganda (Figure 1). It also lies North of the equator at latitude 00 28 ' $\mathrm{N}$ and longitude $32012^{\prime} \mathrm{E}$ and altitude of $3845 \mathrm{ft}$ (1172 m) above sea level.

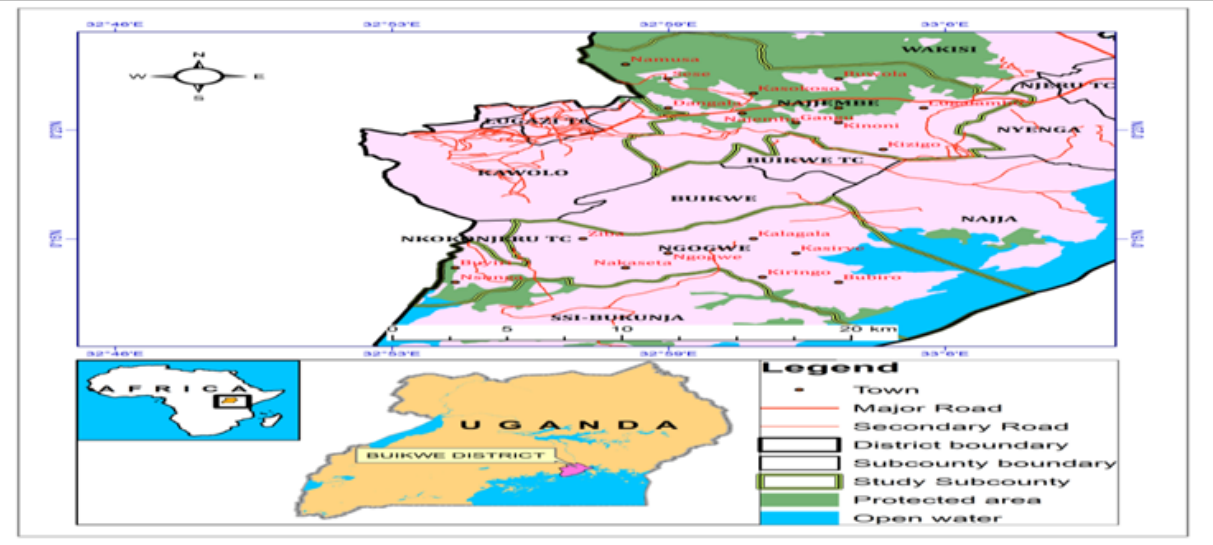

Figure I Map showing the location of the study area in Buikwe District.

\section{Research design}

The study was conducted in Njeru sub-county, Buikwe District. The study focused on the utilization of medicinal plants used in the management of HIV/AIDS opportunistic infections. Ethno-botanical survey was used to identify and document the various plant 5 species used in the management of HIV/AIDS opportunistic infections and in experimental research design was used to identify secondary metabolites and test the bacterial activity of selected medicinal plant extracts used in the management of HIV/AIDS opportunistic infections.

\section{Determination of sample size}

A sample size of 35 traditional medicinal practitioners (TMPs) were purposively selected from the three (3) parishes of Njeru Subcounty after were identified by the local council assistant and only 30 TMPs were duly consulted during the data collection because they are not around.

\section{Data collection method}

Preliminary survey: Field work for the study was conducted to obtain various medicinal plants. Prior to any contact with the local community, the study were introduced to the sub county officer (LC 1) and Village leader through an introductory letter from Islamic University in Uganda. Two research assistants were helped during the course of the study survey. A pilot study lasted for three days at the beginning of the research. In the pilot study, traditional medicinal practitioners (TMPs) were identified with the help of the local assistant as an interpreter.
Plant species identification: Traditional medicinal practitioners (TMPs) were duly consulted. Medicinal plants used for the management of HIV/AIDS opportunistic infections were collected from their habitat with the help of practitioners. On conversations, data on the local names of plants, plant parts used, infection treated, modes of applications were recorded.

Plant collection and identification: A significant number of field trips were undertaken to collect the plant species mentioned in vernacular names during the survey. Plant specimen was taken for identification at Makerere University Herbarium following the procedures described by (Martin, 1995). The plant species were classified using Martin the Key database at www.theplantlist.org accessed on 07/06/2015. The plant materials collected from the parishes of Njeru West (Namwezi village), Njeru East and Njeru South were allowed to air dried at room temperature for 2 weeks to avoid decomposition of volatile chemicals in plant materials.

\section{Method of data analysis}

The data collected were analyzed using both Microsoft Excel and Statistical Package for Social Sciences (SPSS) version 20. Frequency and percentage tables were generated to summarize results for discussion. Pie and bar charts were also used to present results.

\section{Results and discussion}

\section{Demographic information of the respondents}

The majority of the respondents were above 45 years (Table 1). The study was therefore dominated by respondents in the age group 
that had been found to hold a lot of knowledge on medicinal plants in various local communities. Uniyal et al. ${ }^{24}$ reported that elderly people know more about plant use than young worldwide. Few traditional medicinal practitioners were in the age group of the youth. Information from the table implies that 7 majorities of those who participated in the study were old women, female herbalists were more involved in conservation by cultivating the medicinal plant species for easy access and they spent most of their time around homesteads. The TMPs in Njeru were females and less educated.

Table I Demographic characteristic of the respondents $(n=30)$

\begin{tabular}{llll}
\hline Parameters & & Frequency & Percentage \\
\hline Age & $15-25$ years & I & 3.3 \\
& $26-35$ & 2 & 6.7 \\
& $36-45$ & 11 & 36.7 \\
& 45 and above & 16 & 53.3 \\
Gender & Male & 13 & 43.3 \\
\multirow{3}{*}{ Level of education } & Primary & 17 & 56.7 \\
& Secondary & 6 & 76.7 \\
& No formal education & 1 & 23 \\
\hline
\end{tabular}

Source: Field survey (20I5)

\section{Plant species used in the management of HIVIAIDS opportunistic infections}

A total of 52 plants species used in the management of HIV/ AIDS opportunistic infections belonging to 49 genera and 31 families were identified. The families Lamiaceae and Leguminosae had the highest number of species recorded each having 6 and 5 plant species 9 respectively, followed by Moraceae and Verbanaceae in that order (Figure 2) (Table 2). Lamiaceae was used by traditional healers to manage HIV/AIDS infections; including urinary tract, wounds, kidney infection and stomach ache, members of this family contain terpenoids. Terpenoids are biological compounds that can enhance and maintain the body immunity. ${ }^{5}$

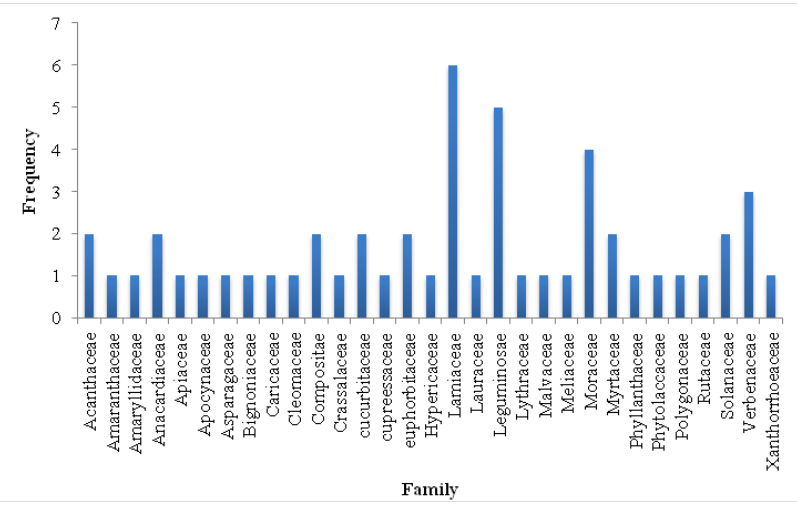

Figure 2 Distribution of the plant species among families.

Table 2 Medicinal plants used for the management of HIV/AIDS opportunistic infections identified and recorded in Njeru

\begin{tabular}{|c|c|c|c|c|c|c|}
\hline Family & Specie & Infection treated & Part used & Mode of application & $\begin{array}{l}\text { Growth } \\
\text { form }\end{array}$ & Freq. \\
\hline \multirow[t]{2}{*}{ Acanthaceae } & Justicia betonica $L$. & Skin infections & Leaves & Decoction drunk & Herb & 1 \\
\hline & Justicia flava (Forssk.) Vahl. & Tuberculosis; Chronic cough & Leaves & Decoction drunk & Herb & I \\
\hline Amaranthaceae & $\begin{array}{l}\text { Chenopodium opulifolium } \\
\text { Schrad. ex.WDJ Koch \& Ziz. }\end{array}$ & $\begin{array}{l}\text { Cryptococcal meningitis; } \\
\text { Tonsillitis }\end{array}$ & Leaves & $\begin{array}{l}\text { Infusion bath; decoction } \\
\text { drunk }\end{array}$ & Herb & 5 \\
\hline Amaryllidaceae & Allium sativum $L$. & Skin infections; Wound & Whole part & $\begin{array}{l}\text { Crushed with jelly smeared } \\
\text { on skin }\end{array}$ & Herb & 2 \\
\hline \multirow[t]{2}{*}{ Anacardiaceae } & $\begin{array}{l}\text { Pseudospondias microcarpa } \\
\text { (A.Rich) Engl. }\end{array}$ & Stomach infections & Leaves & Decoction drunk & Tree & 8 \\
\hline & Mangifera indica $L$. & Tuberculosis; Chronic cough & $\begin{array}{l}\text { Leaves; Stem } \\
\text { bark }\end{array}$ & Decoction drunk & Tree & 6 \\
\hline Apiaceae & Steganotaeni aaraliacea Hochst & Stomach pain;Tuberculosis & $\begin{array}{l}\text { Roots; Stem } \\
\text { bark }\end{array}$ & Decoction drunk & Tree & 1 \\
\hline Apocynaceae & Plumeria rubra L. & Herpes zoster; Skin infection & Stem bark & $\begin{array}{l}\text { Sap mixed with jelly and } \\
\text { smeared on skin }\end{array}$ & Tree & 4 \\
\hline Asparagaceae & $\begin{array}{l}\text { Sansevieria hyacinthoides (L.) } \\
\text { Druce. }\end{array}$ & $\begin{array}{l}\text { Stomach infections; Skin } \\
\text { infection }\end{array}$ & Whole part & Decoction drunk & Herb & 1 \\
\hline Bignoniaceae & $\begin{array}{l}\text { Spathodea campanulata } P . \\
\text { Beauv. }\end{array}$ & Skin infection & Leaves & $\begin{array}{l}\text { Extract with jelly smeared } \\
\text { on skin }\end{array}$ & Tree & 7 \\
\hline Caricaceae & Carica papaya L. & Chronic cough & Leaves & Decoction drunk & Tree & 4 \\
\hline Cleomaceae & Cloeme gynandra $L$. & Skin infection & Flower & $\begin{array}{l}\text { Extract applied on affected } \\
\text { part }\end{array}$ & Herb & 2 \\
\hline
\end{tabular}


Table Continued...

\begin{tabular}{|c|c|c|c|c|c|c|}
\hline Family & Specie & Infection treated & Part used & Mode of application & $\begin{array}{l}\text { Growth } \\
\text { form }\end{array}$ & Freq. \\
\hline \multirow[t]{2}{*}{ Compositae } & Tagetes minuta $L$. & Diarrhea; Dysentery & Leaves & Decoction drunk & Herb & 3 \\
\hline & Vernonia cinerea $(L)$. Less. & Diarrhea; Chronic cough & Leaves & Decoction drunk & Shrub & 2 \\
\hline Crassalaceae & Kalonchoe densiflora Rolfe. & Respiratory infection & $\begin{array}{l}\text { Leaves; Stem } \\
\text { bark }\end{array}$ & Concoction drunk & Shrub & 4 \\
\hline \multirow{2}{*}{ Cucurbitaceae } & Momordica foetida Schumach. & Chronic cough & Leaves & Infusion drunk & Herb & 2 \\
\hline & Luffa cylindrica (L.) M. Roem. & $\begin{array}{l}\text { Respiratory infection; Chest } \\
\text { pain }\end{array}$ & $\begin{array}{l}\text { Stem bark; } \\
\text { Leaves }\end{array}$ & Decoction drunk & Climber & 3 \\
\hline Cupressaceae & Cupressus lusitanica Mill. & $\begin{array}{l}\text { Tuberculosis;Asthma; Chronic } \\
\text { cough }\end{array}$ & $\begin{array}{l}\text { Stem bark; } \\
\text { Leaves }\end{array}$ & Concoction drunk & Tree & 3 \\
\hline \multirow{2}{*}{ Euphorbiaceae } & Jatropha circus Linn. & Chronic cough; Diarrhea & Root; Leaves & Decoction drunk & Shrub & 2 \\
\hline & $\begin{array}{l}\text { Euphorbia candelabrum } \\
\text { Tremaux ex Kotschy. }\end{array}$ & Warts; Tuberculosis & Whole part & Decoction drunk & Herb & 4 \\
\hline \multirow[t]{2}{*}{ Hypericaceae } & Psorospermum febrifugue Spach & Herpes zoster, Skin infection & Leaves & $\begin{array}{l}\text { Extract with jelly smeared } \\
\text { on skin }\end{array}$ & Tree & 7 \\
\hline & $\begin{array}{l}\text { Solenostemon latifolius (Hochst. } \\
\text { Ex. Benth) JK Morton }\end{array}$ & Candidiasis; Oral ulcer & Leaves & Concoction drunk & Herb & 5 \\
\hline \multirow{5}{*}{ Lamiaceae } & Tetradenia riparia (Hochst) & Stomachache; Ulcer & Leaves & Decoction drunk & Herb & 5 \\
\hline & Hoslundia opposita Vahl. & Candidiasis; Sore throats & Leaves & Infusion drunk & Herb & 1 \\
\hline & Ocimum gratissimum L. & Stomach infections & Leaves & Decoction drunk & Herb & 3 \\
\hline & Plectranthus barbatus Andrews. & Skin infections; herpes zoster & Leaves & $\begin{array}{l}\text { Crushed and applied on } \\
\text { affected part }\end{array}$ & Shrub & 4 \\
\hline & Leonotis nepetifolia (L.) R Br. & Stomach infections & Leaves & $\begin{array}{l}\text { Chewed and decoction } \\
\text { drunk }\end{array}$ & Herb & 2 \\
\hline \multirow[t]{2}{*}{ Lauraceae } & Persea americana Mill. & $\begin{array}{l}\text { Chronic cough; Chicken pox; } \\
\text { Stomach ulcer }\end{array}$ & $\begin{array}{l}\text { Leaves; Stem } \\
\text { bark }\end{array}$ & Decoction drunk & Tree & 3 \\
\hline & Senna didymobotrya (Fresen.) & Fungal infections & Leaves & Concoction drunk & Tree & 2 \\
\hline \multirow[t]{4}{*}{ Leguminosae } & Erythrina abyssinica DC & Stomach infections & $\begin{array}{l}\text { Leaves; Stem } \\
\text { bark }\end{array}$ & Concoction drunk & Tree & 5 \\
\hline & Albizia coriaria Oliv. & Diarrhea; Chronic cough & Stem bark & Infusion drunk & Tree & II \\
\hline & Entada abyssinica A Rich. & Chronic cough; Tuberculosis & Stem bark & Decoction drunk & Tree & 2 \\
\hline & Tamarindus indica $L$. & Diarrhea & Leaves & Infusion drunk & Tree & 1 \\
\hline Lythraceae & Punica granatum $L$. & $\begin{array}{l}\text { Skin infection; wound; } \\
\text { stomach ulcer }\end{array}$ & Seed; Roots & Chewed and swallowed & Shrub & 2 \\
\hline Malvaceae & Sida cordifolia L. & Warts, swollen limbs & Leaves & $\begin{array}{l}\text { Crushed and smeared on a } \\
\text { swollen part }\end{array}$ & Herb & 4 \\
\hline \multirow[t]{2}{*}{ Meliaceae } & Azadirachta Indica A Juss. & $\begin{array}{l}\text { Stomach infection; oral } \\
\text { candidiasis }\end{array}$ & $\begin{array}{l}\text { Leaves; Stem } \\
\text { bark }\end{array}$ & Decoction drunk & Tree & 2 \\
\hline & Ficus asperifolia Miq. & Fungal infection; throats ulcer & Leaves & Concoction drunk & Shrub & $\mathrm{I}$ \\
\hline \multirow[t]{3}{*}{ Moraceae } & Artocarpus heterophyllus Lam. & Chronic cough; Chest pain & Stem bark & Concoction drunk & Tree & 3 \\
\hline & $\begin{array}{l}\text { Milicia excelsa (Welw.) CC } \\
\text { Berg. }\end{array}$ & Skin infections & Stem bark & Decoction drunk & Tree & 3 \\
\hline & $\begin{array}{l}\text { Treculia africana Decne. ex. } \\
\text { Trecul. }\end{array}$ & Stomach infections & Roots; leaves & Decoction drunk & Tree & 1 \\
\hline
\end{tabular}


Table Continued....

\begin{tabular}{|c|c|c|c|c|c|c|}
\hline Family & Specie & Infection treated & Part used & Mode of application & $\begin{array}{l}\text { Growth } \\
\text { form }\end{array}$ & Freq. \\
\hline \multirow{2}{*}{ Myrtaceae } & $\begin{array}{l}\text { Callistemon citrinus (Curtis) } \\
\text { Skeels. }\end{array}$ & Chronic Cough & Leaves & Decoction drunk & Tree & 9 \\
\hline & Psidium guajava $L$. & Tuberculosis; Diarrhea & $\begin{array}{l}\text { Leaves; Stem } \\
\text { bark }\end{array}$ & Decoction drunk & Tree & 2 \\
\hline Phyllanthaceae & $\begin{array}{l}\text { Flueggea virosa (Roxb. ex } \\
\text { Wild) Royle. }\end{array}$ & Dysentery; skin infection & Leaves; Roots & Decoction drunk & Shrub & 3 \\
\hline Phytolaccaceae & Phytolacca decandra $L$. & Skin infection; swollen limbs & Leaves & $\begin{array}{l}\text { Crushed and smeared on } \\
\text { affected part }\end{array}$ & Shrub & 1 \\
\hline Polygonaceae & $\begin{array}{l}\text { Rumex usambarensis } \\
\text { Dammer. }\end{array}$ & Skin infection; oral candidiasis & Leaves & $\begin{array}{l}\text { Crushed and smeared on } \\
\text { affected part }\end{array}$ & Herb & I \\
\hline Rutaceae & Zanthoxylum chalybeum Engl. & Chronic Cough;Tuberculosis & $\begin{array}{l}\text { Roots; Stem } \\
\text { bark }\end{array}$ & Decoction drunk & Tree & 2 \\
\hline solanaceae & Solanum lycopersicum L. & Skin infection & Whole part & $\begin{array}{l}\text { Crushed and smeared on } \\
\text { affected part }\end{array}$ & Herb & 3 \\
\hline \multirow{4}{*}{ Verbenaceae } & Solanum nigrum $L$. & Joint pain; chronic headache & Leaves & Decoction drunk & Herb & 2 \\
\hline & Lantana camara $L$. & Chronic Cough & Leaves & Decoction drunk & Shrub & 1 \\
\hline & $\begin{array}{l}\text { Clerodendrum myricoides } \\
\text { (Hochst) R Br. ex.Vatke. }\end{array}$ & Stomach infections; Warts & $\begin{array}{l}\text { Stem bark; } \\
\text { Roots }\end{array}$ & Concoction drunk & Shrub & I \\
\hline & Lantana trifolia L. & Tuberculosis; skin infections & Leaves & Concoction drunk & Herb & 3 \\
\hline Xanthorrhoeaceae & Aloe vera (L.) Burm f. & Skin infections & Leaves & $\begin{array}{l}\text { Sap mixed with jelly smeared } \\
\text { on skin }\end{array}$ & Herb & 3 \\
\hline
\end{tabular}

Most of the plants used were trees and herbs (Figure 3). The most frequently used plant was Albizia coriaria, Callistemon citrinus, Pseodospondias microcarpa, Spathodea campanulata, Psorospermum febrifugue, Solestenostemon latifolius, Tetradenia riparia and Erythrina abyssinica. Thirty four (34) plant species were used to manage more than one condition, with Cupressus lusitanica, Persea americana, and Punica granatum as the only species used to manage more than two HIV opportunistic infections. The most commonly used part of the medicinal plant was leaves, followed by bark and roots in that order (Figure 3). Leaves are commonly used because they have a higher content of bioactive compounds that treats the infection. ${ }^{25}$ The utilization of leaves in local medications inflicting less damaged to the medicinal plants and is advantageous as far as conservation is concerned.

The plant species identified in this study were used to manage twenty eight (28) HIV opportunistic infections. Most of the plant species identified were known to manage skin infections, chronic cough, tuberculosis, stomach infections, diarrhoea, herpes zoster and Warts (Figure 4). Others with low percentage of mention included dysentery, Cryptococcal meningitis, wound, respiratory infections, chest pain, candidiasis, stomach ulcer, fungal infections, swollen limbs, oral candidiasis, tonsillitis, stomach pain, asthma, oral ulcer, stomachache, ulcer, sore throats, chicken pox, throat ulcer, joint pain and chronic headache. Some of the mode of application included decoction drunk, infusion bath, crushed with jelly smeared on skin, extract applied on the affected part, infusion drunk, concoction drunk, chewed and swallowed, crushed and smeared on a swollen part.
Drinking decoction was the commonest mode of application followed by drinking concoction, smearing jelly on skin and drinking of infusion in that order. Similarly this mode of application has been reported to be common in Western Uganda. ${ }^{26,27}$ Use of decoction may be due to the advantages associated with it. Decoction as boiling method is an effective method of preparing medicinal plant because it preserves the medicine longer when compared to cold water. According to Marshall $\mathrm{NT},{ }^{28}$ in traditional medicine, boiling is believed to be efficient in extracting active ingredient and for hygienic reasons. Similarly Asase et al. ${ }^{29}$ observed that the majority of the herbal preparations involved boiling the plant material and then drinking the extract.

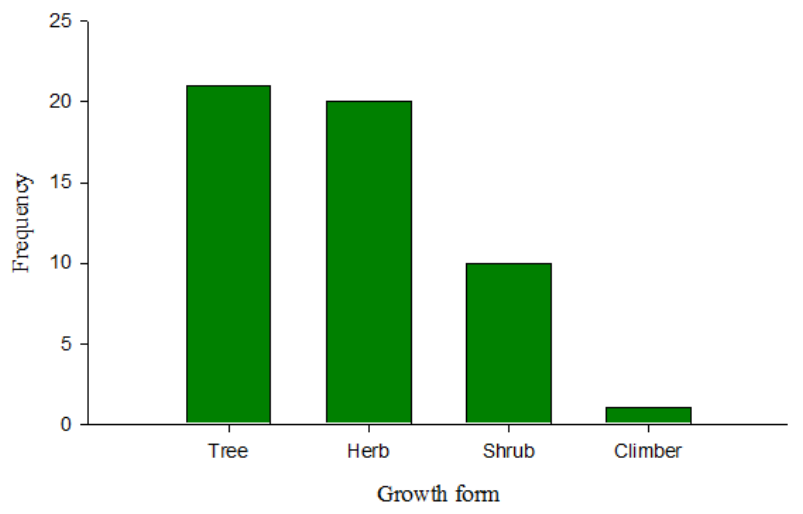

Figure 3 Growth form of the medicinal plant species used in the management of HIV opportunistic infections. 


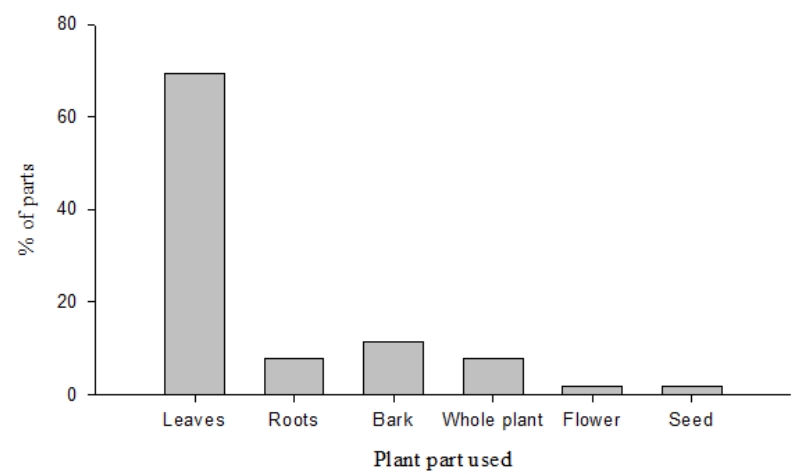

Figure 4 Percentage of medicinal plant parts used.

\section{Conclusion}

Njeru is endowed with a large number of plant species that can be used to manage HIV/AIDS opportunistic infections. A total number of (52) plants species were identified, but the number could even be higher. Plants from the family Lamiaceae, Moraceae, Leguminosae and Verbenaceae were the most frequently used plants. The most commonly used plant part was leaves for the management of HIV/ AIDS opportunistic infections. The plants were used to manage several infections but the most commonly mentioned were skin infections, chronic cough, tuberculosis, stomach infections, diarrhea, warts and herpes zoster. The mode of application used by traditional medicinal practitioners (TMPs) was predominantly by decoction drunk.

\section{Acknowledgements}

We would like to express our deepest gratitude to the local assistants from Njeru town council in person Sheikh Sadeeq and Sheikh Musa who helped me identify local traditional medicinal practitioner and Sokoto State Scholarship Board for the financial support.

\section{Conflict of interest}

The authors declare that they have no competing of interest.

\section{References}

1. Weiss RA. How does HIV cause AIDS? Science. 1993;260(5112):12731279.

2. De Walque D. Who Gets AIDS and How?: The Determinants of HIV Infection and Sexual Behaviors in Burkina Faso, Cameroon, Ghana, Kenya, and Tanzania. Policy Research Working Paper. 2006;(3844):1-51.

3. Amuri M, Mitchell S, Cockcroft A, et al. Socio-economic status and HIV/AIDS stigma in Tanzania. AIDS care. 2011;23(3):378-382.

4. TACAIDS, TCfA. Third Tanzania HIV and Malaria Indicator Survey 2011-2012 (THMIS III). Maryland, USA; 2012. 313 p.

5. Kisangau DP, Lyaruu HV, Hosea KM, et al. Use of traditional medicines in the management of HIV/AIDS opportunistic infections in Tanzania: a case in the Bukoba rural district. J Ethnobiol Ethnomed. 2007;3:29.

6. Mustapha AA. Ethnobotanical field survey of medicinal plants used by traditional medicine practitioners to manage HIV/AIDS opportunistic infections and their prophylaxis in Keffi Metropolis, Nigeria. Asian $J$ Plant Sci Res. 2014;4(1):7-14.
7. Uiso FC, Kayombo EJ, Mbwambo ZH, et al. Traditional healer's knowledge and implications to the management and control of HIV/ AIDS in Arusha, Tanzania. Tanzania Health Research Bulletin. 2007;8(2):95-100.

8. Mbonu NC, van den Borne B, De Vries NK. Stigma of people with HIV/AIDS in Sub-Saharan Africa: a literature review. J Trop Med. 2009;2009:145891.

9. Kala CP, Farooquee NA, Dhar U. Prioritization of medicinal plants on the basis of available knowledge, existing practices and use value status in Uttaranchal, India. Biodiversity \& Conservation. 2004;13(2):453-469.

10. Scheinman D. The ancient and modern worlds unite to fight HIV/AIDS in Tanga, Tanzania. Merck. Science in Africa online magazine. 2002.

11. Schocken C. Overview of the Global Fund to Fight AIDS, Tuberculosis and Malaria. Center for Gobal Development. 2005. p. 1-7.

12. Brugha R, Donoghue M, Starling M, et al. The Global Fund: managing great expectations. Lancet. 2004;364(9428):95-100.

13. Ooms G, Van Damme W, Temmerman M. Medicines without doctors: why the Global Fund must fund salaries of health workers to expand AIDS treatment. PLoS Med. 2007;4(4):e128.

14. Liddell C, Barrett L, Bydawell M. Indigenous representations of illness and AIDS in Sub-Saharan Africa. Soc Sci Med. 2005;60(4):691-700.

15. Chinsembu KC, Hedimbi M. An ethnobotanical survey of plants used to manage HIV/AIDS opportunistic infections in KatimaMulilo, Caprivi region, Namibia. J Ethnobiol Ethnomed. 2010;6:25.

16. Dräger S, Gedik G, Dal Poz MR. Health workforce issues and the Global Fund to fight AIDS, Tuberculosis and Malaria: an analytical review. Hum Resour Health. 2006;4:23.

17. Attaran A, Barnes KI, Curtis C, et al. WHO, the Global Fund, and medical malpractice in malaria treatment. Lancet. 2004;363(9404):237-240.

18. Rukangira E. Medicinal plants and traditional medicine in Africa: constraints and challenges. Sustainable Development International. 2001. pp. 179-184.

19. Delvaux C, Sinsin B, Van Damme P. Impact of season, stem diameter and intensity of debarking on survival and bark re-growth pattern of medicinal tree species, Benin, West Africa. Biological Conservation. 2010;143(11):2664-2671.

20. Lamorde M, Tabuti JR, Obua C, et al. Medicinal plants used by traditional medicine practitioners for the treatment of HIV/AIDS and related conditions in Uganda. J Ethnopharmacol. 2010;130(1):43-53.

21. Kala CP. Status and conservation of rare and endangered medicinal plants in the Indian trans-Himalaya. Biological Conservation. 2000;93(3):371-379.

22. Mhame P, Nyigo VA, Mbogo GP, et al. The management of HIV/AIDS-

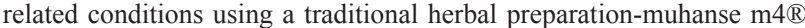
in Tanzania: A case study in Dar-es-Salaam, Tanzania. National institute for medical research, Dar-es-Salaam, Tanzania. 2004.

23. Bannerman RH. Traditional medicine in modern healthcare service. International Relations. 1980;6(5):731-748.

24. Uniyal SK, Awasthi A, Rawat GS. Developmental processes, changing lifestyle and traditional wisdom: analyses from western Himalaya. Environmentalist. 2003;23(4):307-312.

25. Scartezzini P, Speroni E. Review on some plants of Indian traditional medicine with antioxidant activity. J Ethnopharmacol 2000;71(1-2):23-43. 
26. Kamatenesi-Mugisha M, Oryem-Origa H. Medicinal plants used to induce labour during childbirth in western Uganda. J Ethnopharmacol. 2007;109(1):1-9.

27. Hamill FA, Apio S, Mubiru NK, et al. Traditional herbal drugs of southern Uganda, I. J Ethnopharmacol. 2000;70(3):281-300.
28. Marshall NT. Searching for a cure: conservation of medicinal wildlife resources in East and Southern Africa. Traffic International. 1998. 112 p.

29. Asase A, Oteng-Yeboah AA, Odamtten GT, et al. Ethnobotanical study of some Ghanaian anti-malarial plants. $J$ Ethnopharmacol. 2005;99(2):273-279. 